\title{
A maçonaria moderna nas malhas do Santo Ofício no Império Português no Setecentos
}

\section{Modern Masonry in the nets of the $18^{\text {th }}$ Century Portuguese Inquisiton}

Virginia Maria Trindade Valadares*

\begin{abstract}
Resumo
O meu desiderio, nesse estudo é analisar os pedreiros livres no contexto da doutrina Iluminista do século XVIII, assim como as disputas pelo poder entre a Maçonaria e a Igreja Católica, demonstrando aspectos de identidade morais e religiosas entre ambas. No seio da maçonaria setecentista não havia uma identidade única, ao contrário, as opções ideológicas eram um tanto quanto contraditórias, e nem se quer podemos dizê-la politizada, pois apesar de estar aberta ao Iluminismo, com ele não tinha identidade; era antifilosofismo, mas ao mesmo tempo estava distanciada dos cânones da Contra Reforma e do conservadorismo tridentino. Estes maçons, pedreiros livres, foram presos pelo Santo Ofício português por serem considerados hereges e libertinos.
\end{abstract}

Palavras-chaves: Maçonaria. Iluminismo. Inquisição.

\begin{abstract}
My wish, in this study is to analyze the freemasons in the context of the Enlightenment doctrine of the eighteenth century, as the struggle for power between Freemasonry and the Catholic Church, demonstrating aspects of moral and religious identity between them. Within the eighteenth century Freemasonry was not a single identity, in contrast, the ideological choices were somewhat contradictory, and can not even say it politicized because despite being open to the Enlightenment, with he had no identity; antifilosofismo was, but at the same time was distanced from the canons of the Counter Reformation and the Tridentine conservatism. These masons, freemasons, were arrested by the Inquisition Portuguese because they are considered heretics and libertines.
\end{abstract}

Keywords: Freemasonry. Illuminism. Inquisition.

\footnotetext{
* Doutorado em História da Expansão e dos Descobrimentos Portugueses pela Universidade de Lisboa. Pesquisadora do Centro de História d'Aquém e d'Além-mar (CHAM), Universidade Nova de Lisboa. Professora aposentada da UFMG-COLTEC e atualmente professora Adjunto IV do Departamento de História da Pontifícia Universidade Católica de Minas Gerais. E-mail: virmatri@gmail.com
} 


\section{Introdução}

Este texto é um fragmento de pesquisa realizada no pós-doutoramento em Portugal, no período de 2009 a 2012, financiada pela Fundação para a Ciência e Tecnologia - FCT, sediada em Lisboa, e com acolhimento do Centro de História d'Aquém e d' Além Mar - CHAM, pertencente à Universidade Nova de Lisboa. A temática refere-se à Sociedade dos Pedreiros Livres e à perseguição dos seus membros pelo Santo Ofício no século XVIII.

Meu propósito é analisar a categoria dos pedreiros livres como membros das Corporações de Ofício, na Idade Média, e como partícipe, ou não, das ideias iluministas no século XVIII. Os pedreiros livres, no final dos Setecentos, foram presos nos Estãos ${ }^{1}$ do Santo Ofício e alguns até sofreram torturas, como forma de limpar o corpo e salvar a alma. Eles eram considerados pela Inquisição como heréticos, libertinos e movidos não pela lei de Deus, mas pela de Satanás. No entanto, de acordo com os depoimentos dos maçons no Tribunal Inquisitorial, fica claro que muitos ritos usados na simbólica maçônica, guardados as devidas proporções, tinham as mesmas bases dos rituais católicos. Tal fato nos faz crer que as constantes rixas entre a Igreja Católica e a Maçonaria tinham razões menos religiosas e mais políticas: as duas instituições disputavam o poder e a supremacia social.

\section{Pedreiros Livres: Entre o corporativismo medieval e o Iluminismo}

$\mathrm{Na}$ Idade Média, pedreiro era uma das profissões que compunham as Corporações de Ofício, associações profissionais marcadas pela hierarquia, pelo controle da técnica de produção, assim como pela criação de regras para o ingresso na profissão. Essas confrarias também agregavam seus membros para o culto do santo patrono, para a caridade recíproca entre eles e eram ligadas à Igreja. Os pedreiros adotavam, portanto, os estatutos, a organização e até mesmo as terminologias hierárquicas das Corporações, tais como aprendiz, oficial (jornaleiro ou companheiro) e mestre. Nelas não havia sobreposição de competências, sendo os mestres donos das oficinas, acolhedores dos oficiais e responsáveis pelo "adestramento" dos aprendizes.

A Corporação dos Pedreiros tinha, em especial, o segredo da construção, vivendo da régua, do esquadro, do compasso, do nível, do fio de prumo, entre outros instrumentos. Em função do conhecimento da arte de construir, gozavam a confiança do papado e da nobreza, para erigirem catedrais

\footnotetext{
${ }^{1}$ Prisão do Santo Ofício.
} 
e palácios. Os utensílios de que se serviam os pedreiros lhes franqueavam a liberdade de ação, daí a sua denominação de "pedreiros livres", termo derivado do francês franc-maçonnerie, ou do latim sculptores lapidum liberorum. O domínio da técnica da construção civil deu a eles a franquia para exercerem a profissão, possibilitando-lhes a edificação de grandes templos, em sua maioria religiosos, de estradas e pontes e a estreita ligação com a Igreja Católica.

Antônio Carlos de Carvalho nos afirma que o pensamento e a mão do pedreiro eram artesanais: "Só ele é activo perante a passividade da matéria. E os escultores que talharam as pedras das catedrais não pensavam menos profundamente do que os escolásticos". 2

Assim sendo, todo ato destinado a obter um resultado material pode ser considerado como um rito de necessidade, mas tal ato pode ser também uma condição técnica destinada a prolongar o domínio dos seus efeitos. 0 pedreiro livre, essencialmente, não é um artista, mas um artesão que soube talhar a pedra bruta, dando-lhe uma forma e uma construção visível aos olhos do homem. Tal conhecimento, apesar de não conter a erudição escolástica, exigia-lhe um raciocínio experimental e exato, não menos profundo do que o pensamento dos escolásticos, mas com bases diferenciadas, pois enquanto aqueles se baseavam na oratória, os pedreiros norteavam-se pela prática.

Quando nos referimos ao pedreiro livre, que talha a pedra bruta e constrói, estamos falando da chamada Maçonaria antiga e tradicional, que era operativa, formada por artesãos, ligada ao catolicismo e que conciliava a teoria com a prática.

No entanto, o ano de 1717 marca o declínio dessa Maçonaria operativa e tradicional e o nascimento da Maçonaria moderna, também chamada de especulativa. A história moderna da Maçonaria deve, portanto, ser fixada no século XVIII, a partir de 1717, quando na Inglaterra surge a Grande Loja, formada pela reunião e organização de quatro lojas londrinas. ${ }^{3}$

Quatro anos após ter sido organizada a Grande Loja inglesa, no ano de $1721,{ }^{4}$ ela incumbiu o pastor presbiteriano londrino James Anderson de reunir as regras e preceitos adotados na Ordem para elaborar uma constituição

\footnotetext{
${ }^{2}$ CARVALHO, António Carlos. Para a História da Maçonaria em Portugal (1913-1935). Lisboa: Vega, 1993, p. 50. ${ }^{3}$ LAPAGE, Marius. História e Doutrina da Franco-Maçonaria: A ordem e a obediência. São Paulo: Ed. Pensamento, 1967, p. 48.

${ }^{4}$ BRAGANÇA, José Lopes. A Maçonaria e o Cristianismo. Belo Horizonte: Imprensa Oficial, 1987.
} 
maçônica, que, depois de pronta, ficou "sob malhete" 5 por um prazo de cerca de dois anos. Em 1723, o trabalho de Anderson foi revisto por uma comissão oficial da Ordem e, tendo sido aprovado, ficou conhecido como a "Constituição de Anderson", que é o documento básico universal de toda a maçonaria.

Com o nascimento da Maçonaria moderna especulativa e com a criação da Grande Loja inglesa, origina-se também um poder central, uma loja-mãe com atribuições legislativas e definidas por regulamentos de caráter administrativo. Dessa forma, a Grande Loja da Inglaterra provocou a ruptura na Maçonaria: a instituição que, até 1717, era operativa, formada de pedreiros livres construtores, com práticos saberes, a partir dessa data, passa para as mãos de parte dos intelectuais de carisma protestante, tornando-se mais acessível às influências do mundo profano. A esse propósito, Márcio Jardim afirma que a Maçonaria inglesa

[...] apoiou a Casa de Orange contra os Stuarts, representando a defesa do constitucionalismo, do anglicanismo e da independência contra as ameaças do absolutismo francês e espanhol. A luta da maçonaria inglesa apresenta-se como liberal e nacionalista, tornando-se seus adversários símbolos da reação e do catolicismo. Desta forma uniu-se definitivamente, a maçonaria ao trono inglês, anglicano e constitucional. É fundado o que Manoel Rodrigues Ferreira e Tito Lívio Ferreira ${ }^{6}$ chamaram de "Maçonaria Azul".

Em 1725, a Maçonaria fundada na Inglaterra estende sua influência à França e cria em Paris uma Loja nos moldes ingleses. Em 1735, as lojas de Paris solicitaram da Grande Loja da Inglaterra autorização para fundar em França uma Grande Loja Provincial, no que tiveram o pedido negado. ${ }^{8}$ Essa loja, no entanto, acabou por ser formada em Paris, no ano de 1743, com o nome de Grande Loja Inglesa da França. Assim, de acordo com seus interesses políticos e comerciais, a Maçonaria inglesa criou sua Grande Loja não só em França, mas também em Espanha e Portugal. Em Portugal, a Maçonaria precisava atuar na sombra, já que D. João V ameaçou punir gravemente quem fosse iniciado na Sociedade dos Pedreiros Livres. Tal edito vem em obediência à bula do papa Clemente XII, que, desde 27 de abril de 1738, havia proibido

\footnotetext{
${ }^{5} \mathrm{Na}$ linguagem maçônica, "malhete" é um pequeno martelo, de madeira ou de metal, usado pelo Venerável e pelos Vigilantes para dirigirem os trabalhos oficiais. Ver: Emblema de autoridade, vontade e direção. OLIVEIRA MARQUES, A.H. de. Dicionário de Maçonaria Portuguesa. Lisboa: Editorial Delta, 1986, p. 941. ${ }^{6}$ FERREIRA, Manuel Rodrigues; FERREIRA, Tito Lívio. A Maçonaria na Independência do Brasil. São Paulo: Biblios, 1972.

${ }^{7}$ JARDIM, Márcio. A Inconfidência Mineira: uma síntese factual. Rio de Janeiro: Biblioteca do Exército, 1989, p. 18.

${ }^{8}$ LAPAGE, op. cit., p. 48.
} 
os católicos de participarem das lojas maçônicas. A partir desse momento, a confraria adotou, adaptando os rituais antigos, uma metodologia de segredo, mistério e seleção rigorosa dos associados como forma de defesa. Graça e Silva Dias afirmam que a "[...] maçonaria não apareceu feita; foi-se fazendo, isto é, foi se explicitando e concretizando, sob o impulso da sua dialética interna e ao sabor dos estímulos ou travões que lhe vinham do processo histórico global". ${ }^{9}$ De acordo com esses autores, não havia, no seio da Maçonaria setecentista, uma identidade única; ao contrário, as opções ideológicas eram um tanto contraditórias, e nem sequer podemos dizê-la politizada, apesar de a instituição valorizar a presença do sol e da luz nos seus templos e iniciações e estar aberta ao Iluminismo. Não obstante, essa abertura filosófica ao Iluminismo, segundo os mesmos autores, a Maçonaria não tinha total identidade com as luzes, mas também não comungava com os ditames da Contra Reforma e do conservadorismo tridentino.

No que diz respeito à luz decantada no ato da iniciação maçônica, Carvalho considera que esta é:

[...] um segundo nascimento e uma regeneração. Segundo nascimento porque abre ao Ser outro mundo diferente daquele em que exerce a actividade da sua modalidade corporal; regeneração, porque restabelece o Ser nas prerrogativas [...]. Para que o profano se torne iniciado deverá morrer e nascer de novo. Morrer para o mundo profano e nascer no mundo da Iniciação, da Luz. ${ }^{10}$

"Luz", segundo os maçonólogos, é uma palavra muito usada durante a Iniciação para ser admitido na Sociedade dos Pedreiros Livres. Luz, na linguagem maçônica, significa "[...] conhecimento que se recebe ao entrar na Maçonaria, quer do ponto de vista racional e moral, quer simbólico, e cuja intensidade aumenta à medida que se sobe na hierarquia dos graus". ${ }^{11}$ A luz maçônica opõe-se às trevas do mundo profano e pode ser interpretada de acordo com o rito ou em função das características tradicionais da obediência que se pertence. Assim, o termo "iluminado" usado pela Maçonaria aplica-se ao neófito que sai da "Câmara de Reflexões", ${ }^{12}$ porque, em seu

\footnotetext{
${ }^{9}$ DIAS, Graça da Silva; DIAS, José Sebastião da Silva. Os Primórdios da Maçonaria em Portugal. Lisboa: Instituto Nacional de Investigação Cientifica, 1986, p. 4. Os autores de alguma forma ao afirmar que a Maçonaria era antifilosofismo contrariam a opinião de Oliveira Marques, que em obra já citada neste trabalho, afirma que a Maçonaria especulativa era de tipo filosófico.

${ }^{10}$ CARVALHO, op. cit., p. 37-38.

${ }^{11}$ OLIVEIRA MARQUES, op. cit., p. 908

${ }^{12}$ Local onde o neófito ficava para refletir sobre sua vida e decidir se realmente desejava tornar-se maçon.
} 
renascimento, se diz que seu corpo "[...] transpira a luz recebida". ${ }^{13}$ Para o Iluminismo, no entanto, luz significa sair da escuridão política do absolutismo, da ignorância supersticiosa determinada pelo clero, acreditando na iluminação revelada pela ciência e por uma religião libertadora.

Parece claro, portanto, que não se deve confundir a luz maçônica com a luz que se evidencia no movimento iluminista. Da mesma forma, não se pode generalizar afirmando que todos os sócios da maçonaria eram pessoas da vanguarda setecentista e iluminista. Por outro lado, não se pode entender que no movimento iluminista não houvesse uma grande gama de maçons, podendo-se dizer, sim, que todos eram iluminados, mas que essa iluminação não tinha o mesmo significado para iluministas e para maçons.

Tenório D’Albuquerque ${ }^{14}$ chega mesmo a afirmar que a Maçonaria e o Iluminismo jamais constituíram uma mesma coisa; ao contrário, foram grandes e fundamentais os desacordos entre as duas instituições, além de ser inverídico que elas tenham se fundido. Contrariando a opinião de Tenório, Oliveira Marques é categórico ao dizer que existem profundas relações entre o Iluminismo e a Maçonaria, não só pelo espírito comum a ambas, de valorização do homem e da razão, mas também pelo fato de que muitos vultos do Iluminismo se tornaram simpatizantes da confraria. Penso, porém, que, apesar de existirem pontos comuns entre a Maçonaria e o Iluminismo, havia também entre eles grandes divergências, como sobre a concepção de Deus e do universo: enquanto o Iluminismo pregava o deísmo, isto é, a crença em um ser supremo, mas não na sua interferência na vida do homem, os maçons veem em Deus o grande arquiteto do universo. Enfim, como já dito, repito que, nunca existiu uma Maçonaria como centro aglutinador e atemporal, e sim diversas organizações maçônicas. Ela constitui “[...] mais uma forma de organização - ritos e símbolos em diversos locais e épocas - do que uma entidade monolítica e coerente". ${ }^{15}$ Dessa forma, é possível afirmar que não há uma ideologia maçônica coesa, mas sim um conjunto de valores e símbolos. Apesar de defender a crença na perfeição do universo, a Maçonaria tem uma história cheia de contradições, próprias da condição do homem: ao mesmo tempo em que os maçons exercem a solidariedade, eles praticam a traição, fazem acordos e provocam desavenças, e assim como alimentam a esperança dos seus membros, provocam a sua frustração.

\footnotetext{
${ }^{13}$ COUTO, Sérgio Pereira. Dicionário Secreto da Maçonaria. São Paulo: Universo do Livro, 2006, p. 47.

${ }^{14}$ Ver: D'ALBUQUERQUE, Tenório. Maçonaria e a Grandeza do Brasil: verdades que os livros ocultam e a destruição de mentiras que eles divulgam. Rio de Janeiro: Aurora, [s.d], 516p.

${ }^{15}$ MOREL, Marco. A Indústria do Mistério . Revista de História da Biblioteca Nacional. Rio de Janeiro, ano 6, n. 69,2011, p. 16.
} 


\section{Questões conceituais e identitárias entre o Santo Ofício e a Sociedade dos Pedreiros Livres}

Ao analisar os processos da Inquisição de Lisboa, existentes nos fundos do Arquivo Nacional da Torre do Tombo - ANTT, em Lisboa, Portugal, percebe-se que o interrogador do Santo Ofício sabia por oitiva de tudo o que se referia aos maçons e aos seus ajuntamentos. No entanto, as perguntas que os inquiridores lhes formulavam caracterizavam muito mais crimes de heresia e de libertinagem, do que crime de franc-maçons, ou de pedreiros livres. 0 inquérito se iniciava sempre advertindo ao réu que ele não cumpria com os dogmas da Igreja, além de zombar deles. Esse tipo de questionamento ia sendo posto durante todo o processo, e somente no final do interrogatório aparecia a fatigadora pergunta: se ele, depoente, fazia parte da seita maçônica.

Avaliando com cuidado os processos documentais, verifica-se que todos os maçons interrogados afirmavam que, nas lojas que frequentavam nunca se falava mal do Estado nem da Igreja, e descreviam com pormenores as suas reuniões. Tais pormenores, relatados em interrogatório e sob a pressão do Santo Tribunal, nos fizeram ver vários pontos identitários entre a prática católica e a maçônica. Entretanto, como nos demonstra a física, no encontro dos iguais, eles se repelem, e ao se repelirem se rejeitam, e ao se rejeitarem estabelece-se a perseguição dos mais fortes institucionalmente aos supostamente mais fracos na ecclesia dos inconstitucionais.

Ao fim e ao cabo, os maçons explicitavam uma visão que tinham de si próprios, enquanto o Santo Ofício, numa inquirição de tipo, para usar uma linguagem do direito, utilizava as suas prerrogativas supostamente contrárias, no questionamento ao crime dos pedreiros livres.

Exemplificando o acima exposto, no processo de $n^{\circ} 8614$, em que o Santo Ofício inquiria o Padre Dom André de Moraes Sarmento, este diz que:

Esta sociedade tão antiga como os homens tem sido olhada pelos mesmos homens com olhos fascinantes aplicando-lhe idéias umas exóticas, outras criminosas, todas aéreas e poucas verdadeiras [...] todo homem deve conservar um coração incorrupto, apartado dos vícios, despido das funestas paixões e onrado das virtudes que inspira a razão e a humanidade [...] tudo recorre em ser o maçon um homem honrado e verdadeiramente irmão dos seus irmãos [...] uma sociedade de homens que se comprometem entre si a guardarem fidelidade huns aos outros e conservarem entre si igualmente huma espécie de fraternidade sem ofensa das leis o que de ordinário firmam com juramento [...] nunca se costumavam admitir as pessoas da plebe, devendo sempre abulezar se com algum caráter destintivo de nobreza, por armas ou por letras. ${ }^{16}$

${ }^{16}$ ANTT, 1791, Inquisição de Lisboa, Processo nํo 8614. 
A Santa Inquisição, no entanto, formava ao contrário do Padre Dom André, outro conceito sobre a Maçonaria, apoiada nas Bulas Pontifícias de Clemente XII e de seu sucessor Benedicto XIV, os quais concebiam

[...] os homens que professavam a doutrina dos Pedreiros Livres como heréticos, libertinos e de má índole e as suas sociedades como conventículos não só reprovados pelas leis territoriais, mas positivamente proibidas, condenadas, proscritas e anatematizadas pela Igreja como sediciosas e suspeitosas de heresia. ${ }^{17}$

A grande maioria dos governos absolutistas de origem divina dos Estados Europeus, nos finais do século XVIII, por (des)conhecimento da doutrina maçônica, e em razão do segredo mantido nas assembleias da instituição e do juramento dos seus membros, desconfiava dos ajuntamentos dos maçons, avaliando que estes desejavam romper com o poder da Igreja e do Estado. Por isso, a Igreja, em consonância com o Estado, iniciou a perseguição aos adeptos dessa sociedade para impedir qualquer tipo de comprometimento ou saboteamento dos seus poderes, desejando, assim, se autoprotegerem contra o suposto poder de destruição da "pedreirada".

Nos países católicos como Portugal, onde a tradição tridentina era observada na sua essência, essa perseguição foi ainda mais violenta, principalmente porque "[...] viam-se súbditos do Papa confraternizando nas lojas com protestantes de vários matizes e até com judeus, o que era julgado perigoso para a integridade das consciências e a pureza da fé". ${ }^{18}$

o poder só existe do lado de um indivíduo ou grupo que o exerce, se houver outro indivíduo ou grupo que obedeça ao desejo daquele que o exerce. Quando tal não acontece, o poder se desvanece. Assim, trata-se de uma relação triádica, isto é, além do grupo e do indivíduo que exerce o poder, e do grupo e do indivíduo que se submete a esse mesmo poder, a relação inclui, também, a esfera de atividade em que o poder se instaura. ${ }^{19}$

A Inquisição, ao perseguir a Maçonaria, exerce poder sobre ela; esta, no entanto, também exerce poder sobre a Igreja na medida em que ambas são fóbicas em relação à outra. A Maçonaria, com medo do poder inquisitorial do aprisionamento, se retrai e finge obedecer; também o Santo Ofício se sente ameaçado pela ação dos pedreiros livres, como se evidencia no trecho abaixo:

\footnotetext{
${ }^{17}$ ANTT, 1791, Inquisição de Lisboa, Processo no ${ }^{\circ} 814$.

${ }^{18}$ OLIVEIRA MARQUES, António Henrique de. História da Maçonaria em Portugal. Lisboa: Editorial Presença, 1990, p. 28.

${ }^{19}$ VALADARES, Virginia Maria Trindade. Elites mineiras setecentistas: conjugação de dois mundos. Lisboa: Colibri, 2004.
} 
[...] liberdade e igualdade com que os Franc-Maçons pretendem atacar e destruir a Religião, os Tronos e os Estados, ocultando estes dois princípios revolucionários e destruidores debaixo do especioso véu das duas virtudes da caridade e amor fraternal tão decantados e vulgares em todas as lojas maçônicas. Considerava a maçonaria como uma seita sediciosa e perturbadora da tranqüilidade e sossego público. ${ }^{20}$

Nesse sentido, faz-se mister que analisemos algumas das várias faces identitárias entre a ação do Santo Ofício e da Sociedade dos Pedreiros Livres e entre o poder exercido por ambos. Invariavelmente, de acordo com a documentação pesquisada, quando da iniciação de uma pessoa na Maçonaria, este colocava a mão direita sobre os Santos Evangelhos e fazia um juramento de guardar os seus segredos. Da mesma maneira, durante o interrogatório do réu maçom no Tribunal da Fé, o Santo Ofício o fazia jurar guardar segredo sobre tudo o que visse e ouvisse ali e tal juramento também era feito com a mão direita sobre os Santos Evangelhos. A Bíblia torna-se, pois, a identidade cristã entre Igreja e Maçonaria.

Para alguém se tornar membro da Maçonaria, era necessário que fosse indicado por outro maçom, o qual se tornava seu padrinho; no juramento, ele tinha que prometer seguir a doutrina e as virtudes pregadas pela confraria. Ou seja, para as pessoas serem admitidas como pedreiros livres, tinham que passar por um ritual, carregado de simbologias e constituído de regras cerimoniais que usualmente se praticam numa religião ou numa seita. Da mesma forma, para se tornar um membro da Igreja Católica, a pessoa tem que ser batizada - o batismo é o rito inicial para ser cristão. 0 ato do batizado também se realiza através da existência de um padrinho e da obediência à Bíblia, livro da doutrina católica que também servia de guia para os padrinhos maçônicos. Dessa forma, verifica-se que os Santos Evangelhos eram a base do juramento e das promessas tanto dos maçons - seja na iniciação na confraria, seja como réus no Santo Ofício-, quanto dos pais e padrinhos no batismo católico. Não há, portanto, nesse sentido doutrinário, divergências, mas sim similaridades entre a Igreja Católica e a Associação dos Pedreiros Livres.

Outra questão identitária entre as duas instituições diz respeito a seus símbolos e ritos. No templo maçônico, tudo é símbolo: o plano, a forma, as dimensões, a estrutura, a perspectiva, as imagens, as cores e os temas, como também é simbólica a sua linguagem. Na mesma instância e proporções, o símbolo faz parte da ritualística católica, quer na representação das ima-

${ }^{20}$ ANTT, 1799, Inquisição de Lisboa, Processo ํํ 6151. 
gens, quer na santificação de pessoas que, em grande parte, tiveram suas origens ligadas a uma elite branca e com poderes político-econômicos, quer no símbolo do lenho, ou mesmo da água que é benta pelo eclesiástico.

O símbolo, no entanto, é aqui usado como toda coisa manifestada em relação a uma realidade superior, donde o simbolismo pode ser definido “[...] como a representação de uma realidade num certo nível de referência por outra realidade correspondente num outro nível de referência [...]", ${ }^{21}$ sendo este fundamentado na natureza dos seres e das coisas, em conformidade não com o caráter humano, mas com as leis dessa natureza.

Segundo Bourdieu, essa relação de entendimento por símbolos constitui uma forma de poder, a que ele chama de poder simbólico. Tal poder é capaz de constituir, de confirmar ou de transformar a visão de mundo; é um poder quase mágico e se define na relação existente entre os que o exercem e os que lhe estão sujeitos, no campo próprio em que se produz e reproduz a crença. ${ }^{22}$ É, portanto, a confiança na legitimidade das palavras e das coisas que confere ao poder simbólico tanta credibilidade: as cerimônias religiosas ou as simbólicas maçônicas é que dão à Igreja Católica e à Sociedade Maçônica o seu poder e a sua credibilidade. A documentação nos revela que uma boa parte de católicos negociava com Deus, através de promessas e sacrifícios, a realização dos seus desejos, como também aqueles que se tornavam maçons confessavam aos inquisidores que haviam se ingressado na sociedade de pedreiros livres para serem ajudados nos seus negócios. E, apenas poucos revelavam que o haviam feito por curiosidade, para descobrir os segredos da associação maçônica.

Daí a iniciação tanto à Maçonaria, quanto ao catolicismo, não ser democrática nos seus ideais, pois uma e outra exigem a formação de pessoas escolhidas que lhes sigam os preceitos e normas e que estejam aptas social e moralmente a receber ensinamentos que são impostos tanto pela sociedade dos maçons, como pela Igreja romana. Os pedreiros livres, enfim, juravam segredo duas vezes: a primeira quando iniciavam na Maçonaria e a segunda quando eram presos pelo Santo Ofício. A exemplo, no processo 3757, Gregório Freire Carneiro, preso nos cárceres do Santo Ofício a 31 de Janeiro de 1792, afirma:

[...] como via que o juramento maçônico era dado sobre os Evangelhos, julgava ser valido, mas que sendo agora obrigado a dizer a verdade debaixo de outro

\footnotetext{
${ }^{21}$ VALADARES, op. cit., p. 28.

${ }^{22}$ BOURDIEU, Pierre. O Poder Simbólico. Rio de Janeiro: Bertrand Brasil, 1989.
} 
juramento, dado nesta Meza, julga que elle não he valido, pois se o fora não o obrigariam aquebrantállo. ${ }^{23}$

Ainda no que diz respeito ao sentido do juramento, o Padre João Pereira da Silva, presbítero secular, respondendo aos inquisidores sobre o valor do juramento maçônico, diz que "[...] prestou o juramento de segredo debaxo dos Santos Evangelhos na conformidade dos estatutos da mesma Sociedade". ${ }^{24}$

Ao analisar os processos, nota-se o significado do juramento e do segredo transmutado sob forma de poder tanto pela Igreja quanto pela Maçonaria. o juramento do segredo era usado no exercício do poder, na medida em que ambos, tanto o Santo Ofício quanto a Maçonaria, pediam segredo dos seus atos ou aos inquiridos ou aos membros da sociedade. Juramento, de acordo com o Dicionário Houaiss, significa “[...] compromisso solene pronunciado em público [...]”; para Francisco Torrinha, no entanto, é “[...] declarar solenemente; assegurar; obrigar". ${ }^{25}$ Assim, jurar compromisso de segredo em público, tanto para o inquirido do Santo Ofício, quanto para o sócio da confraria maçônica, representava não um ato de liberdade, mas uma obrigação devida, como se não houvesse confiança na verdade proferida - o juramento significaria a certeza da inviolabilidade do segredo institucional.

No sentido social, a palavra poder está relacionada ao homem que vive em sociedade, e seu espaço conceptual pode ir desde a capacidade de agir do homem até a de determinar o comportamento de outro homem, sendo este não apenas sujeito, mas também objeto do poder social. 0 poder sobre o homem é, todavia, distinto do poder sobre as coisas; no entanto, o poder sobre as coisas pode converter-se num recurso para exercer o poder sobre o homem.

Assim, no que diz respeito à significação social do poder, tanto o Santo Ofício quanto a Sociedade dos Pedreiros Livres mostram que a força do poder atua no juramento, no segredo e ainda na pergunta, na resposta, na misericórdia e no perdão. De maneiras diferentes, as duas organizações inquiriam seus denunciados e seus sócios com perguntas e insistência nas respostas. A pergunta feita com maior insistência pelo Santo Ofício aos pedreiros livres era sobre o segredo da seita e os nomes das pessoas que

\footnotetext{
${ }^{23}$ ANTT, 1792, Inquisição de Lisboa, Processo nº 3757, Maço 330-331, Cx. 466.

${ }^{24}$ ANTT, 1792, Inquisição de Lisboa, Processo nº 8613.

${ }^{25}$ HOUAISS, Antônio. Dicionário eletrônico Houaiss da língua portuguesa: versão 2.0. Rio de Janeiro: Objetiva, 2006.
} 
participavam dos conventículos. No entanto, estabelece-se aí um paradoxo, pois ao mesmo tempo em que o Tribunal da Fé pedia segredo aos réus sobre tudo o que se passasse durante o julgamento, tentava obter deles todo o segredo guardado pela Maçonaria. Evidencia-se aí o jogo de poder entre a Igreja e a Sociedade dos Pedreiros Livres, porque o Santo Ofício utiliza a mesma tática da Maçonaria.

As perguntas causam no inquiridor uma sensação de aumento do poder. A documentação consultada é farta na demonstração da elevação desse poder pela Inquisição, na medida em que, a cada maçom que se entregava voluntariamente ao Tribunal da Fé, os inquisidores sempre lembravam que:

[...] tomara muito bom conselho em vir espontaneamente a esta Mesa confessar suas culpas, que portanto deve trazê-las todas a memória, para das mesmas fazer huma inteira e sincera confissão, não impondo a si nem a outrem testemunho falso, porque só o dizer a verdade he o que lhe convém para descargo da sua consciência, salvação de sua alma e bom despacho de sua causa. ${ }^{26}$

O inquirido, entretanto, quanto mais consentia em responder às perguntas inquisitoriais, mais ainda se sujeitava ao inquiridor. A liberdade das pessoas reside, em grande parte, em estar a salvo das perguntas, quando estas constituem uma tirania. Entre iguais, a melhor resposta é aquela que põe fim às perguntas. Quando estas, porém, são elaboradas pelo mais forte, as respostas têm que vir completas, revelando ao outro o que ele deseja saber. As informações, então, são armazenadas para serem utilizadas numa situação posterior, como era, aliás, costume na Inquisição.

$\mathrm{O}$ segredo e o silêncio atuam contrariamente à mudança, na medida em que lhes é vedada a fluidez. O homem silencia-se, segreda, sempre movido pelo medo ou quando não deseja mudanças e transformações. As relações humanas estabelecem-se principalmente por meio da fala, e, portanto, alguém que se guarda no silêncio do segredo torna essas relações rígidas. Acumular todos os segredos pode ser fatal para a pessoa que o faz. Todo segredo se intensifica em seu próprio calor interno, tornando-se explosivo e capaz de abrir-se a qualquer momento. Nesse sentido, o poder que se exerce usando como base o segredo do outro é muito perigoso.

No processo de inquirição da Santa Inquisição a João Licok, este disse aos inquisidores que “[...] se protestava gravemente arrependido, delle pedia

${ }^{26}$ ANTT, 1792, Inquisição de Lisboa, Processo ํํ 8613. 
perdão a esta Meza como filho obediente da Igreja implorando piedade e mizericordia". ${ }^{27}$

Nesse mesmo teor, Joze Marques da Silva, durante a sua inquirição, declara aos "[...] cães do Senhor [...]"28 estar "[...] intimamente arrependido de ter incorrido no desagrado daquelle santíssimo Tribunal esperando todo o perdão e mizericordia, protesto nunca mais ir, nem concorrer direta, ou indiretamente para ellas submetendo-me sempre com a mais religiosa humildade a todo castigo que for servido impor-me". ${ }^{29}$ Nota-se claramente nos dois casos, que o réu maçom, ao pedir humildemente perdão e misericórdia ao inquiridor, fica à mercê deste, o que lhe confere poder, pois somente a ele cabe dar ao réu o perdão em nome da misericórdia.

Analisando o sentido da palavra misericórdia, nem sempre ele se põe na sua forma literal e oficial do documento. Para Houaiss, misericórdia pode significar dó, compaixão, piedade, mas pode também significar a exclamação de alguém que pede que o livrem do castigo, do ato de violência ou da morte; pedido de piedade ou clemência. É nesse sentido que os pedreiros livres interrogados clamavam aos inquisidores, já que, naquele momento, estes exerciam o poder de vida e de morte sobre o detento. Ao pedirem misericórdia aos inquisidores, na verdade lhes pediam que os livrassem da violência e da morte.

Ao suplicarem o perdão, esse perdão nem sempre representava uma confissão de erro por parte dos maçons, já que todos insistiam em que era “[...] huma Sociedade na qual se não encontrava couza alguma que fosse oposta as máximas da religião e Leys da Monarquia, mas sim repetidos officios de piedade para com seus menbros". ${ }^{30}$

O perdão é também uma das armas do poder usada pelo Santo Ofício, pois submete o perdoado àquele que lhe perdoa. Na essência, a Inquisição, ao declarar o seu perdão, fazia-o apenas aparentemente, usando como modelo o Deus bíblico, que não se esquece de uma única alma e perdoa a todas que se arrependem. No entanto, o ato hostil permanece registrado, embora ocultado, pois aquele que supostamente perdoou detém não apenas o domínio sobre o que foi perdoado, mas também a sua gratidão.

\footnotetext{
${ }^{27}$ ANTT, 1792, Inquisição de Lisboa, Processo no 8593

${ }^{28}$ Expressão usada por Miguel Real no seu livro "A morte de Portugal", nos seguintes termos: "Porém, se umas correntes 'matavam' o morto, privilégio dos dominicanos da Santa Inquisição, orgulhosamente autocognominados de os "cães do senhor".

${ }^{29}$ ANTT, 1792, Inquisição de Lisboa, Processo ํํ 8594.

${ }^{30}$ ANTT, 1798, Inquisição de Lisboa, Processo ํo 8600.
} 
Nesse mesmo sentido, António Caetano de Freitas, ao escrever ao inquisidor Antonio Veríssimo Lorre pedindo a sua proteção na avaliação das suas culpas, usa o mesmo argumento pregado pelo Santo Ofício, isto é, o da bondade do Deus bíblico para com todos, insistindo que na Sociedade dos Pedreiros Livres nada havia de contrário à Igreja e aos bons costumes. ${ }^{31}$

Estabelece-se, aí, o comércio do perdão, no qual é acolhido pela graça aquele que se submete. Deus, porém, examina e vigia o comportamento dos seus servos, que serão selecionados graças à sua onisciência. A igreja tem esse papel de, em nome de Deus todo-poderoso, ajudar e perdoar a todos os seus fiéis.

Os maçons presos declaravam ao Santo Ofício que haviam aderido à Maçonaria para serem protegidos e ajudados nas suas finanças e negócios. Ora, se a caridade e a fraternidade eram funções exercidas pela Igreja junto a seus fiéis em nome de Cristo, como poderia outra instituição exercer a caridade e praticar a fraternidade para com seus membros? Assim sendo, a Maçonaria assume com seus sócios o papel que é da Igreja, além de aceitar todo tipo de religião, não impondo, como diziam os inquisidores, a “[...] única religião de Cristo que é a Católica Romana". Nessa disputa de poder, a Sociedade dos Pedreiros Livres passa oficialmente a ser proibida e perseguida em todo o império português, sendo tal perseguição legitimada desde 1738, com a publicação da bula In Eminenti Apostolatus Specula, pelo Papa Clemente VII.

Enfim, a aliança entre o trono e o altar fez com que, no geral, a sociedade portuguesa no Setecentos vivenciasse a insegurança gerada pelo medo inquisitorial, que a fez ao mesmo tempo silenciar e delatar, assim como fingir na sua própria verdade, aceitando conceitos formulados pelo Santo Ofício, como por exemplo: a Maçonaria é diabólica, sua obra satânica e seus componentes libertinos e heréticos. A sociedade setecentista portuguesa torna-se fóbica e ao mesmo tempo denunciante dos maçons, com a convicção de que suas denúncias eram para libertar a consciência e salvar suas almas.

No dizer de Miguel Real, formou-se na sociedade portuguesa em decorrência da repressão inquisitorial, entre outras,

[...] complexo canibalista, que alimenta o desejo de cada pai de família portuguesa se tornar súbdito do chefe ou do patrão, familiar do Tribunal da Inquisição, sicofanta da Intendência-Geral de Pina Manique, informador de qualquer uma das várias polícias políticas, carreirista do Estado, devoto acrítico da Igreja [...] bisbilhoteiro do interior da casa dos vizinhos, denunciador ao superior hierárquico. ${ }^{32}$

\footnotetext{
${ }^{31}$ ANTT, 1794, Inquisição de Lisboa, Processo nº 13503.

${ }^{32}$ REAL, Miguel. A Morte de Portugal. Porto: Campo das Letras, 2007, p. 16.
} 


\section{Considerações finais}

O estudo das chamadas Sociedades secretas, como é o caso da maçonaria desperta pouco interesse aos historiadores brasileiros, haja vista a pouca publicação sobre o assunto. As obras de referência que temos na sua maioria são escritas por maçons com um claro viés laudatório e panegerista. Em Portugal, onde ainda hoje, a maçonaria tem muita respeitabilidade pelo poder que exerce tanto na política como na economia e, até talvez por esta razão o assunto tenha um campo de pesquisa e escrita mais alargadas. No entanto, e apesar disso, ela ainda gera temor na sociedade e continua sendo uma seita satânica que deve ser evitada.

Penso, que o meu estudo traz discussões que esclarecem o real significado da maçonaria, do seu poder e da sua defesa as ideias liberais desfazendo superstições e preconceitos criados pela Igreja Católica. Após essas reflexões, nota-se claramente que a Maçonaria era formada em rede com base na ajuda mútua e na fraternidade, praticando em matéria de religião uma espécie de ecumenismo. Não se exigia dos membros que pertencessem a uma classe social definida, mas todos eram bem-sucedidos. Assim, faziam parte da maçonaria desde representantes da nobreza até intelectuais, padres, grandes e pequenos comerciantes. No caso português o maior número de maçons que se tornaram réus do Tribunal da Fé era militares, seguidos por padres e comerciantes. É de se notar, porém, que os padres que se ingressaram na maçonaria eram secular e grande parte oriunda da Ilha da Madeira. Os militares, na sua maioria eram da marinha e trouxeram por mar as ideias dos pedreiros livres divulgando-as entre os seus congêneres e também no exercito. Houve ainda membros da nobreza que eram maçons, como o Duque de Loulé e vários membros da Academia de Ciências. No entanto, estes nunca foram alvo da ira inquisitorial e sequer foram interrogados. O número de maçons comerciantes foi também significativo e, no dizer deles, tornaram-se maçons para serem ajudados nos seus negócios, quer com empréstimos, quer com maior visibilidade. O Café Nicola em Lisboa chegou mesmo a ser local dos ajuntamentos maçons. Em suas práticas, estavam embutidos o exercício do poder e o prestígio adquirido pela Sociedade, fazendo-a entrar na esfera de poder da Igreja. Disso resultou o embate com o Santo Ofício, que a designava como "huma infame seita tão perturbadora quanto execrável".

Artigo recebido para publicação em 28/10/2014

Artigo aprovado para publicação em 23/11/2014 